\title{
Standarad operational procedure of Keshanjana - An Ayurvedic formulation
}

\section{Research Article}

\section{Dhiman $\mathrm{KS}^{1^{*}}$, Vyas $\mathrm{M}^{2}$, Prajapati $\mathrm{PK}^{3}$, Rathor $\mathrm{AS}^{4}$, Vardhana $\mathrm{P}^{5}$}

1. Professor \& Head, Dept. of Shalakya Tantra, IPGT \& RA, Jamnagar.

2. Senior Research Fellow, Dept. of RS \& BK, IPGT \& RA, Jamnagar.

3. Professor \& Head, Dept. of RS \& BK, IPGT \& RA, Jamnagar.

4. Former Head, Dept. of RS \& BK, RG Govt. PG Ayu. College, Paprola (HP).

5. Asst. Prof. (Selected), Dept. of Shalakya Tantra, NIA, Jaipur.

\begin{abstract}
Masi Kalpana is one of the pharmaceutical formulations in Ayurvedic pharmacy used in variety of pathological conditions mainly in external/local applications. Keshamasi has been propounded in Anjana (collyrium) dosage form mixed with Goghrita as Keshanjana in the treatment of Sukshakshipaka (Dry Eye Syndrome) by Acharya Vagabhatta. This preparation is not in practice; \& owing to the sensitivity of ocular therapeutics issue as the method of preparation and quantity of its ingredients is in obscure manner in the literature, this formulation - Keshanjana was taken up for developing Standard Operative Procedure / standardization and clinical evaluation in Dry Eye Syndrome in an EMR project after a pilot study in a PG thesis work.
\end{abstract}

Key words: Keshamasi, Keshanjana, Shuskakshipaka, Dry Eye Syndrome

\section{Introduction:}

Keshanjana is an Ayurvedic formulation prepared out of Kesha Masi scalp hair ash prepared by burning it by a special pharmaceutical method mixed with clarified Goghrita. This particular preparation is indicated for treating Shushkashipaka (dry eye syndrome*) in both Vagbhatta Samhitas - classical Ayurvedic treatises. A very brief method of preparation of this medicine is given in these classics which as per the knowledge of the author have not been practiced by any one so far.

This topical Ayurvedic formulation in Raskriya Anjana (ointment) dosage

*Corresponding Author:

Prof. KS. Dhiman,

Professor \& Head,

Dept. of Shalakya Tantra,

IPGT \& RA, Jamnagar

Email id-dr_ks_dhiman@yahoo.co.in form was tried by Prabhakar Vardhan , Dhiman KS (1) and was found to be a cost effective, better and comparable with available tear substitutes in the market having no adverse effects. Consequent upon this an EMR project on the Standardization and clinical evaluation of Keshanjana has been granted by CCRAS, Dept. Of AYUSH, GOI, New Delhi wherein the main author is the principal Investigator.

\section{Classical Method of preparation of Keshanjana:}

Cut and washed Scalp hairs are to be mixed with Goghrita and rubbed over the mirror a placed in Samputa and subjected for incineration in a Gajputa. The obtained black mass- Keshmasi thus obtained is to be mixed with Goghrita, thus obtained final product is termed as Keshanjana. In this classical method of 
preparation of Keshanjana amount of ghee to be added in Masi preparation as well as to Keshanjana preparation is not specified. Also the duration of rubbing the KeshaGhrita mass on the mirror is not indicated. To complete these gaps observed in the pharmaceutical process of Keshanjana all operational procedures were recorded and presented as SOPs of Keshanjana which are presented in this article.

\section{Materials and methods:}

\section{Procurement of raw material:}

Male and Female scalp hairs (Kesha) were collected from various saloons in village Paprola and Palampur. Total quantity of raw material was $7 \mathrm{~kg}$.

\section{Pre-treatment of raw materials:}

Foreign materials were removed from the hairs; thereafter hairs (Female \& Male Hairs) were washed with medispirit (Spirit used in medical, surgical and laboratory purpose). Washed hairs were spread over enamel tray and subjected for drying under sun light for 2 days.

\section{Preparation of Masi:}

The Masi was prepared by using Gajaputa. Hairs were smeared with Goghrita on glass slab. After proper mixing, mixture was equally divided in four parts \& kept in four earthen saucers, these saucers were covered by another earthen saucer and junction was sealed by 3 alternate layer of mud smeared cloth and again allowed for complete drying. Then this was subjected for Putapaka in the conventional Puta (30 Angulas $=57 \mathrm{~cm}$ in length, breadth \& height). After placing ignited cow dung cakes \& filling 2/3rd part of the pit with cow dung cakes the Sharava Samputa was kept and remaining $1 / 3$ rd part, was filled with cow dung cakes to cover the Sharava Samputa. After complete burning it was allowed for self cooling. Masi was collected from the inner surface of earthen saucers recovered from Puta after self cooling, and then collected Masi was packed in air tight bags and kept for further processing. Same method was adopted for the preparation of female Keshamasi.

Preparation of Keshanjana and ointments (Male and Female):

The Keshanjana prepared by using male and female Keshamasi by adopting same method. During this process, Masi was transferred into a mixer grinder and sieved through 400 \# to secure least particle size of Masi. Afterward, initially Keshamasi and Goghrita was taken in the ratio of 1:2 and triturated for $6 \mathrm{hrs}$. Then gradually $100 \mathrm{~g}$ of Goghrita was added and triturated again upto the formation of uniform mixture. After complete attrition, the Keshanjana was weighed and filled in to ointment tubes of $3 \mathrm{~g}$. The same process was repeated by using Petrolatum as an ointment base instead of Goghrita.

Table 1: Results and observation during preparation of Keshamasi:

\begin{tabular}{|l|l|l|l|}
\hline Sr. No. & Observation & Male & Female \\
\hline 1. & Scalp hairs & $3 \mathrm{~kg}$ & $3 \mathrm{~kg}$ \\
\hline 2. & Goghrita & $2 \mathrm{~kg}$ & $2 \mathrm{~kg}$ \\
\hline 3. & Yield of $M a s i$ & $630 \mathrm{gm}$ & $630 \mathrm{gm}$ \\
\hline
\end{tabular}

Table 2: Results and observation during sieving:

\begin{tabular}{|l|l|l|}
\hline Observation & Keshmasi (Male) & Keshmasi (Female) \\
\hline Weight of Keshmasi & 400 & 300 \\
\hline Final weight of Keshmasi & 381.9 & 285.6 \\
\hline Loss & 18.1 & 14.40 \\
\hline
\end{tabular}


Table 3: Results and observation during preparation of various formulations:

\begin{tabular}{|l|l|l|l|l|}
\hline Observations & $\begin{array}{l}\text { Male } \\
\text { Keshnjana }\end{array}$ & $\begin{array}{l}\text { Female } \\
\text { Keshnjana }\end{array}$ & $\begin{array}{l}\text { Male } \\
\text { Keshmasi } \\
\text { Ointment }\end{array}$ & $\begin{array}{l}\text { Female } \\
\text { Keshmasi } \\
\text { Ointment }\end{array}$ \\
\hline Weight of Keshmashi $(\mathrm{g})$ & 50 & 50 & 25 & 25 \\
\hline Weight of Goghrita / Petrolatum $(\mathrm{g})$ & 1000 & 1000 & 500 & 500 \\
\hline Duration of trituration (hrs) & 8 & 8 & 8 & 8 \\
\hline Weight of Keshnjana $(\mathrm{g})$ & 1037 & 1032 & 512 & 516 \\
\hline Loss $(\mathrm{g})$ & 13 & 18 & 13 & 9 \\
\hline
\end{tabular}

Table 4: Organoleptic Characters of various formulations:

\begin{tabular}{|l|l|l|l|ll|}
\hline Parameters & $\begin{array}{l}\text { Male } \\
\text { Keshnjana }\end{array}$ & Female Keshnjana & $\begin{array}{l}\text { Male Keshmasi } \\
\text { Ointment }\end{array}$ & $\begin{array}{l}\text { Female Keshmasi } \\
\text { Ointment }\end{array}$ \\
\hline Colour & Jet Black & Jet Black & Jet Black & Jet Black \\
\hline Consistency & $\begin{array}{l}\text { Thick \& } \\
\text { Semi solid }\end{array}$ & Thick \& Semi solid & $\begin{array}{l}\text { Thick \& Semi } \\
\text { solid }\end{array}$ & $\begin{array}{l}\text { Thick \& Semi } \\
\text { solid }\end{array}$ \\
\hline Touch & Smooth & Smooth & Smooth & Smooth & \\
\hline
\end{tabular}

\section{Discussion:}

For the preparation of the Keshamasi, male scalp hair and female scalp hair were selected as per the reference of Ashtang Hridaya Uttara Khanda 16/30. Although no directed indication regarding the gender based nature of raw drug is indicated, however here an attempt was made to prepare Keshanjana from male and female scalp hair as well as compare the same clinically.

Preliminary Shodhana of hairs was done to ensure it absolutely free from hair dye dead tissues, scales and other pathognomic conditions. These were subjected to Putapaka (2) by smearing in a fixed quantity of Goghrita. During Paka, characteristic smell was felt similar to burning of proteins. Hair is chiefly composed of keratin (3), a type of dead protein. During Putapaka, it led to the noxious smell. Smearing in Goghrita was done to ensure uniform heating and avoid the charring of hairs.

Slight variation was observed in the yield of Masi from hairs in both the groups. Average loss encountered was not more than $22 \%$ (Table 1). Loss is due to combustion of proteinaceous material and only carbon particles remains as residue.
This can be confirmed only after subjection to analytical techniques.

Masi procured from Putapaka was sieved through 400 \# mesh to ensure uniform and least particle size. Because, eye is sensitive to particle size larger than 25 microns (4). Thus sieving through aforesaid method has ensured this purpose. Loss observed has been shown in (Table 2). Thus, obtained Masi was divided into 2 groups for preparation of Anjana/ointment. Anjana was prepared by adding Goghrita to Masi and divided into 4 batches each for male and female hairs. Similar pattern was followed for preparing ointment. Ointment was selected to ensure elegant and pleasant dosage form as well as for metering the dose administered in form of Anjana. For preparation of ointment, petrolatum (5) as a base was used. Generally it the most widely used base for preparation of ophthalmic ointments with minimum interference in base material. Base for preparation of Anjana/ointment was affixed at 20 times the base material in both the groups for all the batches. This was achieved after numerous trial and error methods in pilot study.

Trituration of base with Masi was carried out for $8 \mathrm{hrs}$. Trituration ensures 
homogenous mixture of the two components and proper mixing of the drugs. Studies related to trituration process have proved that it leads to further reduction in particle size (6). Attrition causes reduction in particle size and thus ensures minimal irritation to eyes during application of ointment.

Average loss observed in Goghrita as a base was $1.24 \%$ and $1.74 \%$ in male and female Keshanjana respectively (Table 3). Similarly, Average loss observed in petrolatum as a base was 2.48 $\%$ and $1.71 \%$ in male and female Keshanjana ointment respectively. Relatively more loss in ointment group may be due to greasy and super sublime nature of petrolatum and some adherence to vessel during processing.

Goghrita has its own therapeutic properties related to ocular diseases. Presence of Vitamin A (Retinol) is also reported in Goghrita (7), specifically. Further, its indication on a Vata predominant disorder like dry eye syndrome can be relieved to a greater extent by using Goghrita as a base. However, its unctuousness makes its less suitable for preparing formulations. Moreover, bacterial overgrowth in unsterilized formulations is also a matter of concern. Rigid guidelines are followed while preparation of ocular formulations as instillation of medicines is directly into the eyes. Goghrita may fail to quality on these fronts.

On physical parameters, no significant changes were observed in both the groups (Table 4). However, from the point of view of elegance and quality of finished product, Keshanjana ointment can be considered as more standard and refined dosage form in comparison to Keshanjana.
Conclusion:

Overall review of pharmaceutical process ensures that preparation of Anjana dosage form can be modified into ointment form by selecting suitable base and abiding to the procedure mentioned in this paper. As far as Keshanjana is concerned, Anjana prepared from Goghrita and petrolatum was similar in physical characters. However, preparation is more feasible with later for pharmacy scale as well as far as modishness of finished produced is concerned. However, Goghrita has its own therapeutic properties. Therefore, final word can be given only after subjecting both the formulations for clinical trials on dry eye syndrome.

\section{References:}

1. Vardhana Prabhakar, Dhiman K S et al., Managment of Sukshakshipaka (Dry Eye Syndrome) with Parisheka and Keshanjana 2005, HPU, Shimla.

2. Ashtanga Hridaya, Uttara Khanda 16/30, Shrimad Vagbhatta, Ashtanga Hridayam, Shrikantha Murthy K. R. Chaukhamba Krishna Das Academy, Varanasi, 2003.

3. Remington, The Science and Practice of Pharmacy, $21^{\text {st }}$ edition, Volume I, Chapter 44, Page 871.

4. E book, Modern Pharmaceutics, Chapter 13.

5. Remington, The Science and Practice of Pharmacy, $21^{\text {st }}$ edition, Volume I, Chapter 55, Page 1077.

6. Remington, The Science and Practice of Pharmacy, $21^{\text {st }}$ edition, Volume I, Chapter 37, Page 719.

7. http://en.wikipedia.org/wiki/Ghee 